\title{
IS IT ADVANTAGEOUS TO REUSE FRUIT WASTE BIOMASS FROM PROCESSING OF GRAPEVINE (VITIS VINIFERA L.) FOR BRIQUETTE PRODUCTION?
}

\author{
Anna Brunerova, Milan Brozek \\ Czech University of Life Sciences Prague \\ brunerova@tf.czu.cz, brozek@tf.czu.cz
}

\begin{abstract}
Wine making industry represents a significant part of the agriculture sector; a growing area, where grapevine (Vitis vinifera L.) was cultivated, was equal to 7,534 mil. ha in 2015 and produced $275.7 \mathrm{mil}$. hl of wine worldwide (50\% in European regions). Such a large industry produces a great amount of waste materials. During grapevine technological processing (wine production) waste biomass is produced in the form of vineshoots, pruning, stems, seeds or fruit pressings and is commonly used as fertilizer, plowed into soil or burnt. Therefore, the present research deals with the suitability of grapevine residues (fruit biomass) reusing for briquette production purposes. The investigated material consists of the following parts: skins, pulps, seeds and stems, thus, occurred in heterogeneous mixture. The initial form of the material exhibited high moisture content, thus, had to be dried in a laboratory dryer and subsequently crushed and homogenized. The produced briquette samples were densified into cylindrical shape with diameter $50 \mathrm{~mm}$ with different length and weight. Determination of the briquette final quality was stated directly after briquette production. The chemical analysis was focused on the briquette moisture, ash content and calorific value while the mechanical analysis described the mechanical durability and volume density of the briquette samples. The result values of experimental testing proved great level of the moisture content $(5.3 \%)$, ash content $(6.2 \%)$; the gross calorific value was equal to 19.2 $\mathrm{MJ} \cdot \mathrm{kg}^{-1}$ which is a great result. However, the result values of the briquette mechanical quality indicators exhibited low level; the mechanical durability was equal to $28.3 \pm 3.5 \%$, which is an unsatisfactory result. It can be concluded that the investigated material is advantageous for combustion purposes, but the performance of the biofuel was not suitable. This fact offers an opportunity to improve bad mechanical properties of briquettes by mixing with other feedstocks with high lignin content (natural binder).
\end{abstract}

Keywords: wine production, solid biofuel, mechanical durability, renewable energy, agriculture waste.

\section{Introduction}

Fruit biomass is not commonly utilized for energy production nowadays but there are efforts to investigate its possibilities and spread observations about its subsequent utilization into general public $[1 ; 2]$. Production of fruit biomass is mainly ensured by the agriculture sector, as well as, other kinds of biomass, therefore, the amount of specific fruit biomass is influenced by the intensity of specific crop production [3]. Focused on global grape production, approximately 736.7 million hectoliters of grapes were harvested in 2015 while 275.7 million hectoliters of wine were produced from such grapes. The surface area covered by vineyard was about 7,573 million hectare in the same year [4]. Considering the mentioned data, it can be concluded that a great amount of various waste biomass is produced every year within the vine making industry. One of the waste materials originated from the mentioned agriculture sector are vine prunings and stumps. According to the previous study approximately $3-8 \mathrm{~kg}$ of such waste biomass per tree is produced after seasonal pruning and left unused in the fields with no further utilization [5;6].Previous studies reported the possibility of subsequent utilization of grapevine prunings for energy production [7].This trend was supported by another study, which proved vine pruning suitability for combustion due to high hemicellulose and cellulose (high energy content) [8]. Other waste biomass with potential for combustion purposes is also produced directly during wine production in the form of pressed fruit pulps, skins and seeds. Such waste is defined as fruit biomass and is utilized in different commercial businesses. Oil obtained from grape seeds or/and skins is commonly utilized in medicine and gastronomy for decades [9-13], but its utilization was also investigated in animal nutrition nowadays [14].

It can be concluded that waste biomass obtained from wine production, which contains grape seeds besides others, is characterized by high concentration of residual oil; it can positively influence the calorific value of the produced biofuel. Focused on liquid biofuel production, the suitability of mixed fruit biomass from market was proved for production of ethanol [3]. Utilization of different kinds of fruit waste biomass for solid biofuel production was investigated in the previous study; a waste material from production of cherries, peaches, apricots, watermelons and olives was tested in an attempt to determine its energy potential, which was stated at very high level (approximately $19-23 \mathrm{MJ} \cdot \mathrm{kg}^{-1}$ ) [15]. 
Therefore, the main aim of the present paper was to determine suitability of grapevine fruit waste biomass for briquette production due to the statement of the grape waste biomass energy potential and its chemical properties, as well as due to determination of the mechanical quality of the briquette samples produced from the mentioned feedstock material.

\section{Materials and methods}

The experimental part of the present research was conducted to the mandatory technical standards, which are stated by law and definedetail information about feedstock materials, briquette samples, production processes and tests of briquette quality and its evaluation. Specifically, the mandatory technical standards EN 643 (2014) [16], EN 15148 (2010) [17], EN ISO 17831-2 (2015) [18], EN 14918 (2010) [19], EN ISO 17225-1 (2015) [20], EN ISO 18122 (2015) [21], ISO 1928 (2010) [22], EN 15234-1 (2011) [23], EN ISO 18134-2 (2015) [24], EN ISO 16559 (2014) [25] and EN ISO 16948 (2016) [26].

\section{Sample preparation}

Raw material used as a feedstock for briquette production originated from the wine making industry area located near Velké Bílovice city (South-Moravian region), Czech Republic. The investigated material was a biological waste obtained during technological processes of wine production and was collected directly after fruit pressing. The waste material occurred in the heterogeneous form and was identified as a fruit biomass because it contained predominantly grape skins, pulps and seeds, however, it also contained minor amount of stems. The present raw waste material precisely represented biological waste, which is produced within wine production which exhibited extremely high moisture content-containers with waste also contained fruit juice. High level of the moisture content indicated that unprocessed raw investigated material was not suitable for briquette production and had to be dried in the laboratory dryer LAC type S100/03 (Rajhrad, Czech Republic); the achieved level of the moisture content was equal to $6.43 \%$. Subsequently, the dried material was crushed by the electric powered garden shredder HECHT type 6224 (Tehovec, Czech Republic) to achieve the suitable particle size to be a feedstock material for briquette production.

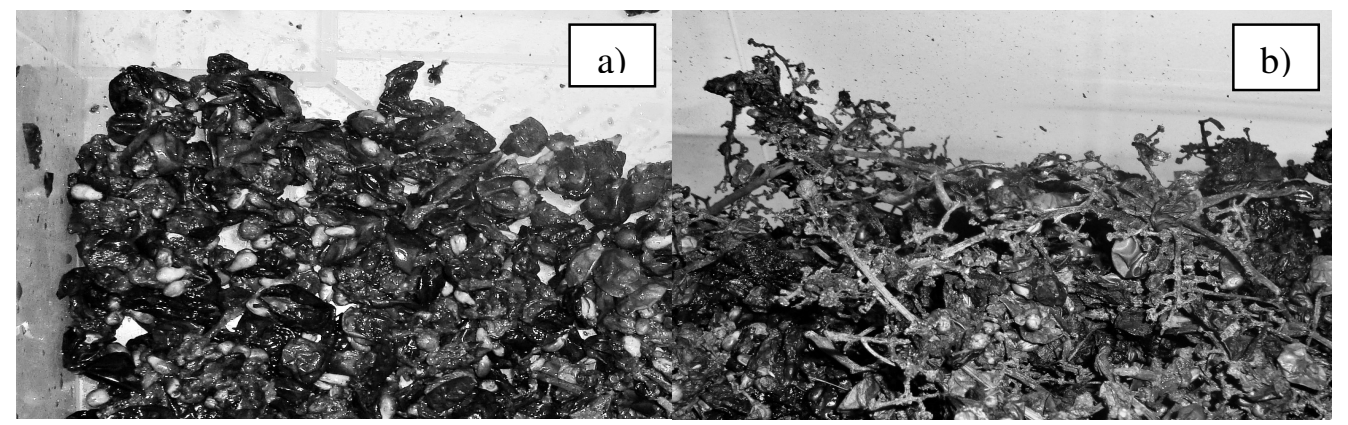

Fig. 1. Feedstock material - grapevine fruit waste biomass: $a$ - raw state; $b$ - dried state

For densification of properly prepared feedstock material a hydraulic piston briquetting press Briklis type BrikStar 30-12 (Malšice, Czech Republic) was used. All produced briquette samples were cylindrically shaped with the dimensions (values in average) noted in Table 1, see below.

Mechanical properties of produced briquette samples

Table 1

Mector

\begin{tabular}{|c|c|c|}
\hline Length, $\mathbf{~ m m}$ & Diameter, $\mathbf{m m}$ & Weight, $\mathbf{g}$ \\
\hline $61.24 \pm 4.89$ & $51.09 \pm 0.43$ & $148.34 \pm 11.4$ \\
\hline
\end{tabular}

\section{Measurement methodology}

Within the chemical analysis the material was investigated subjected to determination of the basic parameters, which describe its properties and energy potential, namely, the moisture content, ash content, volatile matter content, net calorific value and gross calorific value. A thermogravimetric analyzer LECO type TGA 701 (Saint Joseph, United States) was used for experimental measurements related to moisture, ash and volatile matter contents. While the isoperibol calorimeter LECO type AC 
600 (Saint Joseph, United States) was used for the determination of the energy potential of the investigated material, namely, of the gross calorific value, while the net calorific value was calculated and stated in accordance to the mandatory technical standard ISO 1928 (2010) [22].

Within determination of the mechanical quality of the produced briquette samples the mechanical durability and rupture force were stated. The procedure of mechanical durability testing is conducted according to the mandatory technical standard EN ISO 17831-2 (2015) [18] and the present indicator describes the ability of the briquette samples to resist to directed impacts and remain intact during destruction testing. As a testing equipment, a special dustproof rotating drum powered by electricity was used and the result values expressed the amount of material which was lost during testing. Rupture force determination is not defined by any standard, however, it described the maximal loading force, which the briquette samples were able to endure before their destruction. As a source of loading force the hydraulic universal tensile compression testing machine ZDM 5t (VEB, Dresden, Germany) (loading speed $20 \mathrm{~mm} \cdot \mathrm{min}^{-1}$; maximal loading force 50,000 N) was used.

\section{Results and discussion}

The present chapter was divided into two separate parts; the first one was related to the chemical properties of the investigated material (grapevine waste biomass) in an attempt to define its suitability for combustion purposes from the perspective of its harmlessness for environment during burning. The second part was focused on the mechanical quality of the subsequently produced briquette samples within the statement of their strength and resistance during transportation and handling, which describes the efficiency of the present material utilization for briquette production.

\section{Chemical quality indicators}

The investigated material was subjected to determination of the basic chemical properties represented by moisture, ash and volatile matter contents as well as its energy potential in the form of calorific values was stated; two measurements were performed to determine the Gross calorific value and subsequently the Net calorific value of the present material. Detailed result values obtained from experimental testing are noted in Table 2.

Table 2

\section{Chemical properties of investigated material}

\begin{tabular}{|c|c|c|c|c|}
\hline $\begin{array}{c}\text { Moisture } \\
\text { content, \% }\end{array}$ & Ash content, \% & $\begin{array}{c}\text { Volatile matter } \\
\text { content, \% }\end{array}$ & $\begin{array}{c}\text { Gross Calorific } \\
\text { Value, } \mathbf{M J} \cdot \mathbf{k g}^{-1}\end{array}$ & $\begin{array}{c}\text { Net Calorific } \\
\text { Value, } \mathbf{M J} \cdot \mathbf{~ k g}^{-1}\end{array}$ \\
\hline 6.43 & 6.6 & 86.3 & 19.17 & 17.94 \\
\hline
\end{tabular}

The moisture content noted in Table 2 was measured after the previous drying process, which was necessary because the raw unprocessed material contained predominantly fresh fruit pulps. The measured level of moisture content was suitable for briquette production [20], which was also proved in practice by uncomplicated production of briquette samples. The result value of the ash content indicated a satisfactory result in comparison with other fruit biomass as waste from processing of Dates $(2.65 \%)$ or Jatropha press-cake $(4.36 \%)$ [27]. Nevertheless, the obtained result exhibited higher (undesirable) level of ash content ifcompared with woody biomass the ash content of which is usually $<0.5 \%$ [28]. In case of the Volatile matter content (VMC) a low level is required according to the related standard EN 15148 (2009) [17]; wood sawdust exhibited VMC equal to $47.79 \%$ and Switchgrass equal to $69.14 \%$ according to the previous studies [29]. Energy potential of the investigated material expressed by the Gross and Net calorific values exhibited high level. Previous studies proved the gross calorific value equal to $20.39 \mathrm{MJ} \cdot \mathrm{kg}^{-1}$ for grape seeds and the gross calorific value of different waste biomass originating from wine making industry, specifically vine prunings, ranged from 18.74 to $19.19 \mathrm{MJ} \cdot \mathrm{kg}^{-1}[7 ; 15]$. Thus, it can be concluded that the wine making industry produces waste biomass with high energy potential for combustion purposes and heat generation.

\section{Mechanical quality indicators}

The first parameter investigated in the present chapter was the volume density of the produced briquette samples. Evaluation of the measured values and subsequent calculation proved the volume 
density at high level according to the related technical standard ISO 13061-2 (2014) [30]; it indicates that the mandatory briquette volume density must be $>1,000 \mathrm{~kg} \cdot \mathrm{m}^{-3}$. The specific value is noted in Table 3 below, together with the result values of other performed tests and distribution of all measured values is expressed as a BoxPlot in Fig. 2.

Table 3

\section{Mechanical properties of investigated material}

\begin{tabular}{|c|c|c|}
\hline $\begin{array}{c}\text { Mechanical } \\
\text { durability, \% }\end{array}$ & $\begin{array}{c}\text { Rupture force, } \\
\mathbf{N} \cdot \mathbf{m m}^{-\mathbf{1}}\end{array}$ & $\begin{array}{c}\text { Volume density, } \\
\mathbf{~ k g} \cdot \mathbf{m}^{-\mathbf{3}}\end{array}$ \\
\hline $28.3 \pm 3.5$ & $19.11 \pm 6.3$ & $1183.21 \pm 48.5$ \\
\hline
\end{tabular}

The observed level of mechanical durability (DU) of grapevine fruit waste briquettes was the weakest point of the whole experimental research. The result equal to $28.3 \%$ (see in Table 3) proved extremely low level of the most important indicator of the briquette mechanical quality. Briquette samples produced for commercial purposes must achieve DU at least at level $90 \%$; high quality briquette biofuels must achieve DU $>95 \%$ (EN ISO 17831-2,2015) [18]. Considering these facts, it must be concluded that the produced briquette samples investigated in the present research did not fulfill the required quality demands.
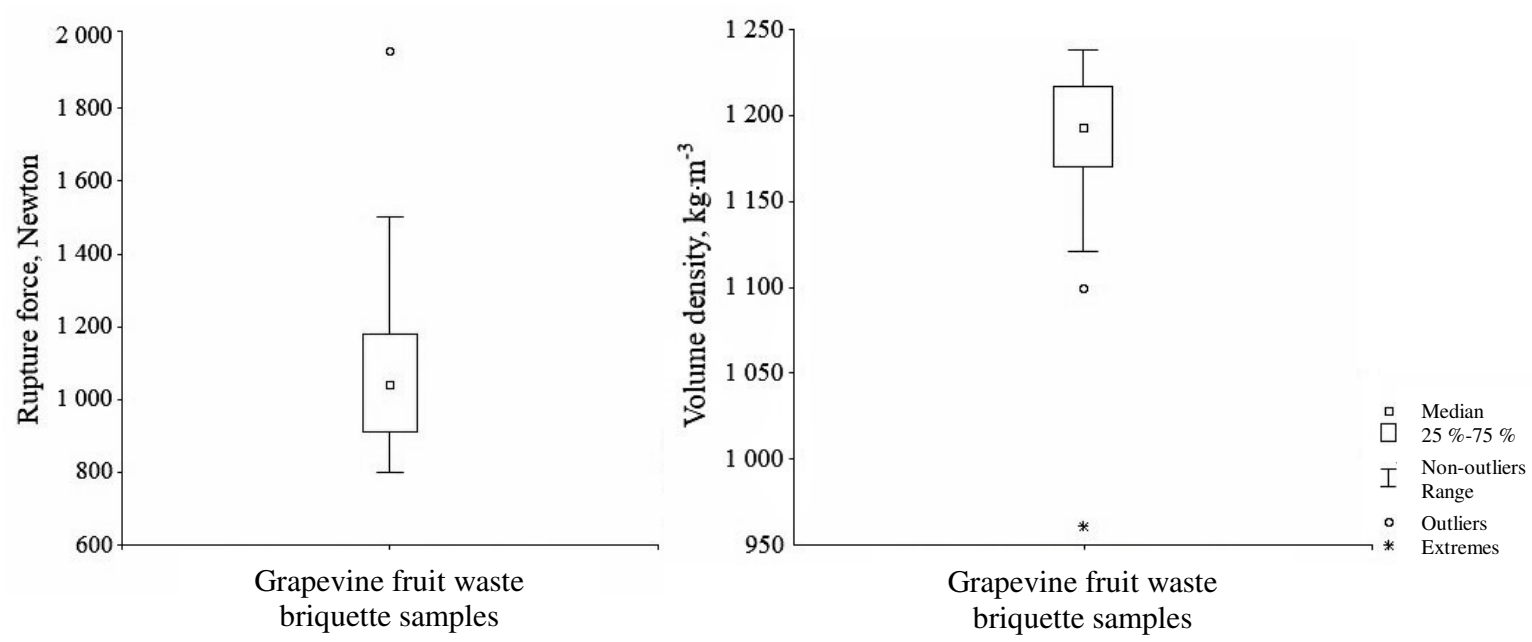

Fig. 2. Mechanical quality indicators of investigated briquette samples

The last performed test was determination of the rupture force $(\mathrm{RF})$; the specific result valueis noted in Table 3 and the distribution of all measured values are expressed in Figure 2, while Figure 3 shows the investigated briquette sample before and after rupture force testing while the deformation of the samples is clearly visible.

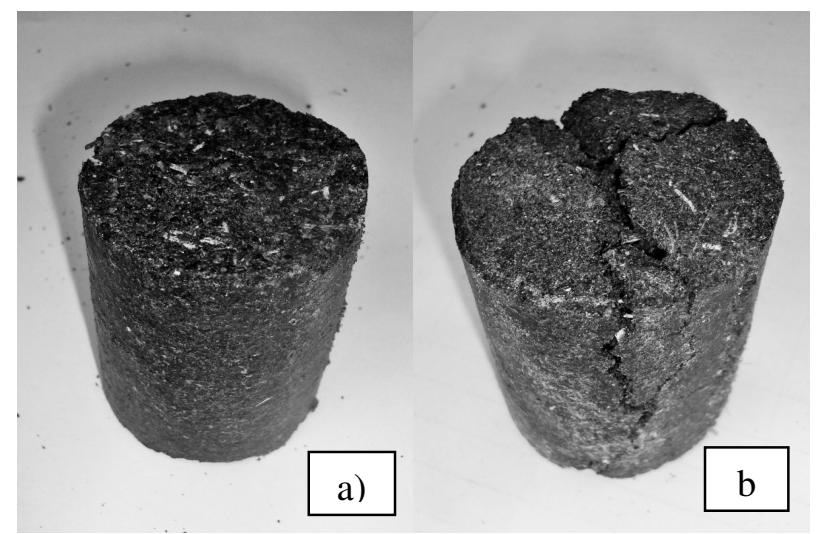

Fig. 3. Grapevine fruit waste briquette samples: $a$ - before RF test; $b$ - after RF test 
Comparison of the obtained result of the rupture force indicated low level of the present test in comparison with RF of wood sawdust briquettes $\left(58.2 \mathrm{~N} \cdot \mathrm{mm}^{-1}\right)$ or wood bark briquettes $\left(31.5 \mathrm{~N} \cdot \mathrm{mm}^{-1}\right)[31]$.

\section{Conclusions}

The result values obtained within quality testing of briquettes produced from grapevine fruit waste biomass indicated contradictory evaluation. Chemical analysis proved great level of energy potential for heat generation, however, inappropriately high moisture content of raw material was observed, thus, extra energy and personal input for drying was consumed. Focused on the investigated mechanical properties, it was also not possible to evaluate them unambiguously. The briquette sample volume density achieved high level, but the mechanical durability exhibited extremely low level, as well as the results of rupture force. Thus, the answer to the question in the title of the present paper cannot be definite. If we consider grapevine fruit waste biomass unmixed in $100 \%$ concentration, it is not suitable for briquette production due to low mechanical resistance and strength of such briquettes, nevertheless, it is suitable for combustion purposes due to the high energy potential and chemical composition. Considering the mentioned facts, it can be recommended to use the present material for combustion purposes in different forms. Undesirable bad properties of grapevine fruit waste biomass briquettes can be eliminated by mixing with other materials (with high concentration of lignin), thus, they could be used as an additive to feedstock mixture. Grapevine fruit waste biomass would ensure an increase of the energy potential of mixture and the second selected material would ensure increasing of the mechanical quality of the produced briquettes.

\section{Acknowledgment}

The research was supported by Internal Grant Agency of the Faculty of Engineering, Czech University of Life Sciences Prague, grant number 2017:31140/1312/3112 and further by the Internal Grant Agency of the Czech University of Life Sciences Prague, grant number 20173005 $(31140 / 1313 / 3108)$.

\section{References}

1. Lashley M.A., Thompson J.R., Chitwood M.C., Deperno Ch.S., Moorman, Ch.E., 2014. Evaluation of Methods to Estimate Understory Fruit Biomass. PLoS ONE 9(5).

2. Pessoa M.S., Rocha-Santos L., Talora D.C., Faria D., Mariano-Neto E., Hambuckers A., Cazetta E. 2016. Fruit biomass availability along a forest cover gradient. Biotropica 49(1), pp. 45-55.

3. Lalitha G., Sivaraj R. 2011. Use of fruit biomass peel residue for ethanol production. International Journal of Pharma and Bio Sciences, 2(2), pp. 15-23.

4. Aurand J. M. 2015. The major challenges of the vitivinicultural sector: role and strategy of the OIV Director General - OIV Member States Intergovernmental organization of scientific and technical nature 33, 1-41.

5. Nasser R.A., Al-Mefarrej H.A., Abdel-Aal M.A., 2011. Suitability of Vine (Vitis vinifera L.) Prunings for Wood-Cement Industry. American-Eurasian Journal of Agricultural \& Environmental Sciences 11(6), pp. 903-910.

6. Ntalos G.A., Grigoriou A.H. Characterization and utilisation of vine prunings as a wood substitute for particleboard production. Industrial Crops and Products 16(1), 2002, pp. 59-68.

7. Nasser R.A., Salem M.Z.M., Al-Mefarrej H.A., Abdel-Aal M.A., Soliman S.S. Fuel characteristics of vine prunings (Vitis vinifera L.) as a potential source for energy production. BioResources 9(1), 2014, pp. 482-496.

8. Tsai W.T., Lee M.K., Chang Y.M. Fast pyrolysis of rice straw, sugarcane bagasse and coconut shell in an induction-heating reactor, Journal of Analytical and Applied Pyrolysis 76(2), 2006, pp. 230-237.

9. Pardo J.E., Fernández E., Rubio M., Alvarruiz A., Alonso G.L. Characterization of grape seed oil from different grape varieties (Vitis vinifera). European journal of lipid science and technology, 111(2), 2009, pp. 188-193. 
10. Jayaprakasha G.K., Selvi T., Sakariah K.K. Antibacterial and antioxidant activities of grape (Vitis vinifera) seed extracts. Food research international, 36(2), 2003, pp. 117-122.

11. Maier T., Schieber A., Kammerer D. R., Carle R. Residues of grape (Vitis vinifera L.) seed oil production as a valuable source of phenolic antioxidants. Food Chemistry, 112(3), 2009, pp. 551-559.

12. Rabak F. Grape-Seed Oil. Journal of Industrial \& Engineering Chemistry 13(10), 1921, pp. 919-921.

13. Charradi K., Mahmoudi M., Bedhiafi T., Kadri S., Elkahoui S., Limam F., Aouani E. Dietary supplementation of grape seed and skin flour mitigates brain oxidative damage induced by a highfat diet in rat: Gender dependency. Biomedicine \& Pharmacotherapy 87, 2017, pp. 519-526.

14. Ragni M., Vicenti A., Melodia L., Marsico A.G. Use of Grape Seed Flour in Feed for Lambs and Effects on Performance and Meat Quality. In: APCBEE Procedia.B.m.: Elsevier B.V. 2014, pp. 59-64.

15. Gravalos I., Xyradakis P., Kateris D., Gialamas A. T. An Experimental Determination of Gross Calorific Value of Different Agroforestry Species and Bio-Based Industry Residues. Natural Resources 7, 2016, pp. 57-68.

16. EN 643, 2014: Paper and board - European list of standard grades of paper and board for recycling.

17. EN 15148, 2010: Solid biofuels - Determination of the content of volatile matter.

18. EN ISO 17831-2, 2015: Solid biofuels - Determination of mechanical durability of pellets and briquettes - Part 2: Briquettes.

19. EN 14918, 2010: Solid biofuels - Determination of calorific value.

20. EN ISO 17225-1, 2015: Solid biofuels - Fuel specifications and classes - Part 1: General requirements.

21. EN ISO 18122, 2015: Solid biofuels - Determination of ash content.

22. ISO 1928, 2010: Solid mineral fuels - Determination of gross calorific value by the bomb calorimetric method and calculation of net calorific value.

23. EN 15234-1, 2011: Solid biofuels - Fuel quality assurance - Part 1: General requirements.

24. EN ISO 18134-2, 2015: Solid biofuels - Determination of moisture content - Oven dry method Part 2: Total moisture - Simplified method.

25. EN ISO 16559, 2014: Solid biofuels -- Terminology, definitions and descriptions.

26. EN ISO 16948, 2016: Solid biofuels - Determination of total content of carbon, hydrogen and nitrogen.

27. Brunerová A., Malat’ák J., Müller M., Valášek P., Roubík H. Tropical waste biomass potential for solid biofuels production. Agronomy Research 15. 2017, In press

28. Van Loo S., Koppejan, J., 2002. Handbook of biomass combustion and co-firing. Enschede, Netherlands: Twente University Press.

29. Tilman D., Balzer C., Hill J., Befort B.L.. Global food demand and the sustainable intensification of agriculture. In: Proceedings of the National Academy of Sciences, 2011, pp. 20260-20264.

30. ISO 13061-2, 2014: Physical and mechanical properties of wood -- Test methods for small clear wood specimens - Part 2: Determination of density for physical and mechanical tests.

31. Brožek M., Nováková A., Kolářová M. Quality evaluation of briquettes made from wood waste. Research in Agricultural Engineering 58(1), 2012, pp. 30-35. 